\title{
Mastery and Slavery: A Masochist Falls Asleep Reading Hegel
}

\author{
Albrecht Koschorke
}

(1)

Among the defined sexual perversions, two emerged from the literary laboratory and bear the names of authors. As is well known, the term sadism refers back to Donatien Alphonse François, the Marquis de Sade (1740-1814). Leaving aside some excesses in the Lacoste ancestral castle ${ }^{1}$ and in Paris, Sade's sadism basically involved a monumental prison-fantasy. For its part, the term masochism has an Austrian origin: the writer Leopold von Sacher-Masoch (1836-1895), whose propensities in the waning nineteenth century were so public that the psychiatrist Krafft-Ebing named the complex of sexual pleasure from pain after him. ${ }^{2}$

Masoch's novel Venus in Furs can be considered masochism's founding literary text. It appeared in 1870 , and is one of his few books that still can be read with pleasure. The narrative opens on a gallant note, the initial scene being located in a salon: "My company was charming," we read. ${ }^{3}$ The visitor is none other than the heroine of the title:

${ }^{1}$ cf. Henri Fauville. La Coste. Sade en Provence. Aix-en-Provence: Edisud, 1984.

${ }^{2}$ The following is based on my study Leopold von Sacher-Masoch. Die Inszenierung einer Perversion. München, Zürich: Piper Verlag, 1988, esp. 84ff and 152ff.

${ }^{3}$ Leopold von Sacher-Masoch. Venus in Furs. A Novel. Letters of Leopold von SacherMasoch and Emilie Mataja. Trans. Uwe Moeller and Laura Lindgren. New York: Blast Books, 1989, 53. 
Opposite me by the massive Renaissance fireplace sat Venus; she was not a casual woman of the half-world, who under this pseudonym wages war against the enemy sex, like Mademoiselle Cleopatra, but the real, true goddess of love.

She sat in an armchair and had kindled a crackling fire, whose reflection ran in red flames over her pale face with its white eyes, and from time to time over her feet when she sought to warm them. ${ }^{4}$

The love-goddess freezes. This renders her a fragile creature: "She had wrapped her marblelike body in a huge fur and rolled herself up trembling like a cat." ${ }^{5}$ The conversation concerns the cooling of antiquity's bright religion of love in the Christian north: "To you," Venus observes, "nature seems something hostile; you have made devils out of the smiling gods of Greece, and out of me a demon." 6 With its prehistory extending back to the Middle Ages, this is a German Romantic topos, to be found in Eichendorff and elsewhere. The marble woman presents herself as a victim of a plunge in erotic temperature accompanying the advent of Christianity and, in its wake, bourgeois morality.

But Venus's interlocutor cannot rest content with such a nostalgic complaint. He leans toward another way of seeing things: "But you cannot deny," he protests, "that man and woman are mortal enemies, in your serene sunlit world as well as in our foggy one." Consequently, sexual estrangement has not been introduced into the world as a cultural phenomenon, but has always been there as a natural fact. The male speaker's credo, with which Venus ends up agreeing, is thus as follows: in the long term, no harmony is possible between the sexes, but only a despotic relationship; and the only open question is who takes which role within the structure.

The novel has here entered on its theme. From a variety of angles, it repeatedly follows through on the figure that love is only possible at the price of servitude. All the play of role and conversation centers around this idée fixe, wandering as it does through a narrative construct composed of several levels of action. Namely, we eventually learn that the meeting with Venus has only been dreamt: that the frame-story's narrator had been inspired for Venus's apparition by an oil painting hanging in the hearth-lit room of his friend Severin von

\footnotetext{
${ }^{4}$ Sacher-Masoch. Venus in Furs 53.

${ }^{5}$ Sacher-Masoch. Venus in Furs 53.

${ }^{6}$ Sacher-Masoch. Venus in Furs 55.

${ }^{7}$ Sacher-Masoch. Venus in Furs 56.
} 
Kusiemski. In turn, the painting bears witness to Severin's great erotic adventure-the actual narrative center of the novel.

Imparted to the narrator in the form of a manuscript, this affair is initiated in a Galician watering place. And just as in its entirety, the interior action, framed by the cozy philosophizing of the friend by the fireplace, has the form of a book within a book, the love story from which it emerges is tied to transmission through a book. Lodging in Severin's vicinity, the cultivated Wanda von Dunajew asks him for reading material. In one of the volumes he supplies her, he has left a photo of a painting of Venus by Titian, along with some verses written down on the back side. In this manner, a bookmark offers Wanda knowledge of Severin's erotic predilection. Inversely, she is herself introduced to the narrative in the form of a substitute: when Severin encounters her for the first time, he confuses her in the moonlight with a Venus-statue until then the object of his complete devotion.

Two series of exchanges propel the narrative forward. On the one hand, we have the delivery and receipt of written presents that are interlinked chainlike, and that connect Wanda, the object of desire, Severin, the narrator of the frame-story, and, finally, author and reader. On the other hand, we have the metamorphoses of the Venusfigure, running in both directions in the form of statue, painting, pose, and daemonic-living being.

This leads to the novel presenting not so much a clear temporal narrative sequence as a system of reflections. Dreaming of Venus, the narrator mirrors himself in his protagonist Severin, who has experienced what has been intimated in his dream. For his part, Severin has a doppelgänger, a German painter who falls for Wanda in the same way as he. Wanda herself is the coming to life of different art-objects. The asymmetrical love between her and her adorer Severin propagates itself in reading matter, wall-paintings, mirror-images, citations of myth. The plenitude of signs and intimations in Venus in Furs merely fans the largely invariable underlying pattern, multiplying it through a generation of countless parallels. In the end, the form of the narrative thus amounts to a vibrating, ecstatic stagnation.

Just as all the female figures in Venus in Furs are merely makeshift masks of one and the same figure, the male accompanists are related to one another along a grid of identifications. The book's encapsulated design can only be conveyed through an encapsulated sentence: 
Sacher-Masoch, already notorious for his disposition toward women in furs, writes a novel whose frame-narrator waxes eloquent about despotic women in furs and dreams of such a woman, fantasized along the lines of a salon-painting by a friend, who has lived and suffered through a liaison with the painting's original, and so on.

But what prompts the initial dream, source of the sequence of transposed texts and images? Why does the nameless narrator fall asleep in bright daylight, in order to abandon himself to his erotic phantasmagoria?

"It is really disgraceful," says Severin's servant as he awakes him: "“To fall asleep in your clothes and with a book besides.' He snuffed the candles, which had burned down, and picked up the volume that had fallen from my hand. 'With a book by'-he looked at the title page-'by Hegel. Besides it is high time you were starting for Mr. Severin's, who is expecting us for tea."

Hence in its own way, the dream opening the narrative to all that follows represents a reading scene. Venus's appearance is accompanied by a book tumbling from the dreamer's hand-a book by Hegel. The first significance of the philosopher's name is simply a book so boring as to induce sleep. Beyond this, the afternoon reading of Hegel suggests a mixture of idle fantasy and the pretensions of the Bildungsbürger. Severin has his guiding cultural spirits, too: "Hippocrates, Hufeland, Plato, Kant, Knigge, and Lord Chesterfield."9 Through their canon of reading the two friends in the provincial Galician city of Kolomea are defined as oddballs. For Poe, already, a taste for German philosophers was a sign of ponderous excess. ${ }^{10}$

Most likely, little more than this should be read into the lexeme "Hegel" at the start of Venus in Furs. We ought not overestimate either Sacher-Masoch's philosophical education or the richness of his work's intellectual allusions. At the same time, if we do not shrink from speculation, one touchpoint allows us to endow the mention of Hegel with more interpretive weight: the connection of everything in Venus in Furs with its main motif, submission: in Hegel's collected works, the rubric of Unterwerfung has a single entry-one that furnished it with a certain proverbial familiarity possibly facilitating its slipping into the associative horizon of a writer like Sacher-Masoch. Its locus is the section on master and slave in the Phenomenology of Spirit. In any event,

\footnotetext{
${ }^{8}$ Sacher-Masoch. Venus in Furs 58.

${ }^{9}$ Sacher-Masoch. Venus in Furs 59.

${ }^{10} \mathrm{cf}$. his Morella, with its reference to Fichte and Schelling.
} 
regardless of whether the association falls into the intentional field of Sacher-Masoch, considering Venus in Furs as a sort of countercommentary to the idealist dialectic certainly helps clarify the novel's erotic logic.

\section{(3)}

Hegel elucidates the problem of domination and submission in the capital on self-consciousness. Other than the case with that form of consciousness turned toward the world of perception, self-consciousness is social, constituting itself through its encounter with another selfconsciousness. In Hegel's words: "There exists for Self-Consciousness another self-consciousness; Self-Consciousness has come out from itself. This has the following double-signification: Self-Consciousness has lost itself, since it finds itself as another being; thereby it has superseded the other, since it also does not view this other as a being, but sees itself in the other."11

A complex movement thus emerges of the self's self-abandonment and self-appropriation-a doubly valent gesture in both directions, since every act of self-consciousness is also located in the other, only achieving concord with itself through the other:

As Consciousness, Self-Consciousness does indeed go outside itself; nevertheless, in its otherness it is simultaneously withdrawn into itself-it is a foritself; and its externality to itself is also for-Self-Consciousness. The fact exists for-Self-Consciousness that it immediately is, and is not, the other consciousness; and likewise, the fact that this Other is only for-itself to the extent that it supersedes itself as an existing for-itself; it is for-itself only in the existence-for-itself of its "other." Each consciousness is for the other the "middle term" through which each mediates and unites itself with itself; and each is to itself and to the other an immediate being existing for-itself, which at the same time is for-itself in this fashion only through this mediation. The consciousnesses recognize themselves as mutually recognizing each other. ${ }^{12}$

Anerkennung-acknowledgment or recognition-is the mode of realized reflection on the presence of das Eigene-one's own self-in the other and of the other in one's self; it consists in a perception of the

${ }^{11}$ Hegel's Phenomenology of Spirit. Selections. Trans. and annot. Howard P. Kainz. University Park: Pennsylvania State University Press 1994, 50.

${ }^{12}$ Hegel. Phenomenology $52 \mathrm{f}$. 
fact that both forms of self-consciousness are only present in mutual relation to each other-a relation comprising alienation and identification to an equal degree. Correspondingly, Hegel conceives social inequality as an asymmetry in the acknowledgment-relationship. It can come into play because the relation between the two exemplary forms of self-consciousness contains an initial moment of deep enmity. For from Hegel's vantage, what each person first recognizes in the other is a being who, in the actuality of his or her being, is both real and resistant. Each person wishes to annul this resistance, perceived as negating one's self: an antagonism aimed at the entire entity, and again on both sides. Consequently, at this stage of consciousness both parties desire nothing less than "the death of the other":

But in this orientation the second action, action-through-oneself, is also at hand; for the former action implies the risking of one's own life. The relationship of both self-consciousnesses is thus determined in such a way that they prove the mettle of themselves and the 'other' through a battle to their death. They must enter this battle because they must raise their selfcertainty (about existing for-self) to truth in the 'other' as well as in themselves. ${ }^{13}$

Until this point, the relationship is reciprocal. But the two forms of self-consciousness emerge from the mutually deadly negation with very different characteristics. They now encounter each other "as two opposed Configurations of consciousness, one of which Configurations is the independent consciousness, for which the essential thing is existence-for-self, the other of which is the dependent consciousness, for which the essential thing is its life, or existence-for-another. The former is the Master; the latter, the Slave." 14

How does this difference come into being? According to Hegel, the answer involves the unequal stakes with which the opponents enter the fray: the slave has not been able to "free himself in battle" from concern for his life, his material existence, while the master has indeed done so, such concern having "only negative worth for him." Hence where the slave remains chained to material being as the "object of desire," 15 the master has become capable of exercising authority over simple existence through the absolute risk he was ready to run.

\footnotetext{
${ }^{13}$ Hegel. Phenomenology 54-55.

${ }^{14}$ Hegel. Phenomenology 57-58.

${ }^{15}$ All citations Hegel. Phenomenology 58-59.
} 
With this, a third element has been introduced-one to which master and slave have a diverging relationship that determines the lack of balance between them. This element is the world of "things," or, put otherwise, nature. To be sure, the slave, simply qua "selfconsciousness," is also "related negatively to the Thing," and transcends or "supersedes" it. But:

the Thing is, at the same time, encountered as something independent so that the Slave is not able-with all of his negating - to be finished with the Thing to the extent of doing away with it completely; in other words, he merely 'works the Thing over' [...] but the Master, having interposed the Slave between the Thing and himself, teams up by this stratagem only with the dependence of the Thing, thus attaining to the pure enjoyment of the Thing; the aspect of the Thing's independence is, however, relegated by the Master to the Slave, who works on it. ${ }^{16}$

Through labor, the slave influences the material world, taking on the role of producer. The master is exclusive beneficiary of the production, entertaining a merely indirect, which is to say consumptive, relation to the sphere of things. Until this moment of the exposition, it appears that only the master enjoys the predicate of autonomy, while the slave, both in his social circumstances and his relation to the nature he must cultivate, is consigned to a dependent status. But Hegel does not let things rest here. The dialectic of acknowledgment guiding his analysis of mastery and subjection moves beyond such a simple schema.

In the process of social differentiation, "a one-sided and unequal recognition" 17 has emerged between slave and master. The selfconsciousness of the master finds its acknowledgment in the dependent and to this extent "inessential" consciousness of the slave; his "truth" is "the servile consciousness." 18 His servility itself experiences a dialectic turn; "in its development," it will "turn out to be the opposite of that which it is in its immediacy. Slavery, as a consciousnessforced-back-on-itself, will come to itself and convert itself into true independence." 19

At first glance, the master appears free, the slave subjected. But the master's position is, in fact, one of hermeneutic dependence on his counterpart; he is thus as it were affected by the latter's subjection.

\footnotetext{
${ }^{16}$ Hegel. Phenomenology 59-60.

${ }^{17}$ Hegel. Phenomenology 61.

${ }^{18}$ Hegel. Phenomenology 61.

${ }^{19}$ Hegel. Phenomenology 61-62.
} 
Alexandre Kojève suggestively comments on Hegel's argumentative volte-face to the effect that the master's liberty turns out a dead-end: in order to be realized, it needs to be acknowledged by a slave-the acknowledging person thus needing to be rendered such. ${ }^{20}$ But owing his social prestige, paradoxically, to a diminution of the very person meant to confirm it is not the master's only problem: at the same time, he has maneuvered himself into a position without egress in relation to the third player in the social game-to nature. Where through his labor, the slave has made himself socially indispensable, thus gaining the social initiative, the master only participates parasitically in the production process. In the absence of enduring profit, he abandons himself to consumptive pleasures. Otherwise with the slave in his seemingly dependent mode of action:

In contrast with this Moment of Desire in the Master, work is inhibited desire, delayed disappearance; that is, work forms. The negative relationship of Desire to the object becomes the form of the object, something stablesince it is precisely for the worker-giving-form that the object has independence. This negative 'middle term', that is, formative action, is at the same time the individuality or the pure existence-for-self of consciousness. This existence-for-self being externalised now in work, consciousness steps into the element of stability. The working consciousness thus comes through its formative activity to the intuition of independent existence as its very own self. ${ }^{21}$

Servitude consequently emerges with the truly productive social status. It not only makes possible a complete formation of the material world, but a complete formation of one's own self. "To be sure," Kojève comments:

like the master, like human beings in general, the slave is determined by the real world. But because the world has been transformed, he alters himself. And because $h e$ is the one who has transformed the world, $h e$ is the one who alters himself, while the master is only altered by the slave. The historical process, the historical becoming of the human essence, is thus the labor of the worker-slave, not the warrior-master. ${ }^{22}$

On the one hand, we might tie Hegel's idea to the Marxist hope for emancipation of the oppressed; on the other hand, we might find it sufficient to grant the slave the role of cultural catalyst. In being

${ }^{20}$ Alexandre Kojève. Introduction à la lecture de Hegel. Leçons sur la Phénomenologie de lEsprit. Paris: Ed. Raymond Queneau, 1968, 177.

${ }^{21}$ Hegel. Phenomenology 63.

${ }^{22}$ Kojève. Introduction 179. 
forced-in Hegel's formulation-to restrain his "desire," rendering "that first positive moment," "fear,"23 into a formative activity pointing beyond what is sensuously present, he manifests more mettle in his struggle with the alternate consciousness. He can display patience, since he is sure of the final word from the long-range, world-historical vantage.

\section{(4)}

The frame-narrator of Venus in Furs could have grasped Hegel in this or a similar manner-if only he had not fallen asleep in the reading. But despite the presence of a simply oblivious reader in this reading scene, a kind of hypnomnetic mechanism may be at work here. For the masochistic fantasy running, in ever-new variants, through Venus in Furs generates effects of reversal and subversion displaying remarkable affinity with Hegel's philosophical speculation.

In order to see this, we need to consider the circumstances surrounding the novel's genesis. In 1869, Sacher-Masoch enters into a private contract with a certain Fanny von Pistor, a Baroness with literary pretensions. For a fixed period, he will be her slave. His only provisos are the inviolability of his bourgeois honor and some agreedon time set aside each day for undisturbed work. Everything else is at his mistress's caprice. The pair embarks on an Italian journey, with Sacher-Masoch figuring as a suitcase-bearing lackey and the introduction of certain elements of masochistic ritual (furs and whip; a rival's appearance on the scene). In his breaks from work, Sacher-Masoch writes Venus in Furs, which presents more or less the same narrative.

The agreement with Fanny von Pistor is the first of a series of agreements that Sacher-Masoch makes the basis of his amorous relationships. The provisos in the first contract will vanish in the later versions. The most unrestrained contract is his written declaration of subjection to Wanda, the woman he married (her real name was Aurora; urged by her husband, she would change it to that of the heroine of Venus in Furs). In the declaration, Sacher-Masoch abandons all his personal rights, with no restraints or time-limits-indeed, he makes his life itself a contractual object. Wanda's account of her life attests to the seriousness with which her husband took this business: he can only struggle through to the written self-abandonment

\footnotetext{
${ }^{23}$ Hegel. Phenomenology 64.
} 
he has himself devised after a long period of hesitation, and his signature is invested with all the weight of a heroic decision.

Cast in this light, masochism emerges as one variant-set in the small format of a private perversion-of modern theories of contractual rule. Just as for Hobbes, human beings living in a state of nature submit to their sovereign in a single, irrevocable legal act, in order to enter into a regulated state order, the masochist solemnly submits to his chosen mistress, in order to enter into the phantasmagoric order. And as with Hobbes, Sacher-Masoch's contracts suffer from a threshold paradox: they institute autonomous subjects who have nothing more urgent to do than abandon their autonomy.

What is the source of this procedure's pleasure? Wherein lies the profit to be earned from this self-abandonment cloaked in legality? The masochist merely appears to give up all his rights: this not only because breaking his promise would not have been judicable in nineteenth-century Austria, but also because he is by no means content with a purely submissive role within the erotic ritual. Despite all self-stylizing into victim of his mistress's unfettered caprice: the masochist knows very well how to assure primacy for his pleasureprinciple, hence his own thoroughly selfish erotic interests.

In the same manner as the submission-contract in Venus in Furs, the contract with Fanny Pistor contains a clause making this evident: "Fanny Pistor promises to wear furs as often as feasible, and especially when she is beastly [grausam]" ${ }^{24}$ - a virtually identical formulation being found in the novel. ${ }^{25}$ Hence even the capricious gestures of the dominatrix bear the fetishistic garb of the masochist's instructions. This pattern dominates the erotic ritual in its entirety. While torments are indeed meted out to the willing male protagonist, his abandonment strictly follows rules he himself has devised. Playing the part of victim on a perverse stage, behind the set he is in fact the director.

The masochist leads the woman, imagined as beastly and overbearing, along lines fixed by his own choreography. This results in both participants constantly falling out of their roles: the apparent dominatrix because she sees herself forced into a game that is not her own; the apparent slave because, in open contradiction to his

\footnotetext{
${ }^{24}$ The contract is included in the appendix to the German edition of SacherMasoch's novel, Venus im Pelz. Mit einer Studie über den Masochismus von Gilles Deleuze. Frankfurt a. M.: Insel Verlag 1980, 139.

${ }^{25}$ Sacher-Masoch. Venus in Furs 147-48.
} 
formally declared lack of rights, he supervises the game's parameters and rearranges them according to need. Within this game, the woman can, in the end, only lose everything. And this, precisely, is the hidden goal of the masochistic ritual.

Immediately after Fanny von Pistor has more or less completely fulfilled her obligation toward Sacher-Masoch, the eccentric writer leaves her. He extracts a divorce from his wife, whom he had forced for years into a liaison with someone else, on grounds of infidelity. The dynamic of the relations in Venus in Furs is itself aimed at morally discrediting the same beloved elevated to dominatrix; in the all-tooaccurate fulfillment of his wishes, Severin sees nothing other than a transgression of the boundaries that had been agreed on. Worst yet, he here sees betrayal. ${ }^{26}$

Suprasensuality is the ever-recurring attribute Sacher-Masoch assigns his literary heroes. "Confessions of a Suprasensual Man" is the title of the manuscript in which Severin records his erotic adventure.$^{27}$ Like the Christian martyrs, they are not "soft, sensual, yielding" natures, but "suprasensual men who found enjoyment in suffering. They sought out the most frightful tortures, even death itself, as others seek joy." ${ }^{28}$ They come from a realm of chasteness, transformed into one of horror through their succumbing to the woman's dark enchantment; after a hard cure, they return to the spiritual world that is their real home.

For Sacher-Masoch, the man's seduction is always a seduction of spirituality. It signifies the death of virtue, the triumph of nature. The ritual's sense is to play this triumph of nature until the end-marked by both the catastrophe of passion and a restoration of the man's moral integrity through the endurance of punishment. Thought, the initial chastity, succumbs to passion; but the masochistic game consists precisely in staging chastity as passion. At the initiation's end stands the validated new beginning - the higher rebirth of the ascetic. In its essence, the masochistic pleasure-fantasy is a purification ceremony, a fantasy of lust's annihilation. Its true victim is not the man, but the woman: she leaves the field a loser, pursued by the masochist's subtle scorn..$^{29}$

\footnotetext{
${ }^{26}$ cf. Sacher-Masoch. Venus in Furs 205-7.

${ }^{27}$ Sacher-Masoch. Venus in Furs 62.

${ }^{28}$ Sacher-Masoch. Venus in Furs 89-90.

${ }^{29}$ cf. Theodor Reik's classical analysis Masochism in Modern Man. Trans. Margaret H. Beigel and Gertrud M. Kurth. New York: Farrar, Strauss, 1941.
} 
As with Hegel, Sacher-Masoch turns the opening domination-scenario into its opposite. Because-within the mythology of masochism-the woman is by nature boundless (as are the stakes with which she plays) she can gain mastery in the battle of the sexes. Pure pleasure defines her sexual being, while the man's desire has clear-cut limits-those demarcated by desire's displacement into a punitive realm. But at the same time, the man's independence endows him with a capacity for a working through of the amorous affect lacking on the female's part. Erotic servitude is bound up with a striving to something higher, a suprasensual rapture, which gradually leads to an accumulation of symbolic capital by the subjugated man. In the end, he can withdraw acknowledgement-within the masochistic scene, fetishistic cathexis from his dominatrix: her possession of this role depends entirely on her slave-who turns from her in full sovereignty once she has been stripped of her charm.

Is Venus in Furs thus an experimental arrangement, presenting Hegel's dialectic of slave and master in the form of a love story? And with or without the author's knowledge, might Sacher-Masoch's fictive narrator embody, so to speak, Hegel's transformative figure, in order to recast it in the dreamed dialog with the despotic lovegoddess and the emerging interior narration?

In face of the evident parallels, we ought not lose sight of the basic difference between Hegel's Phenomenology and Sacher-Masoch's Venus in Furs. Putting aside the distinction of genres, this mainly involves two factors. The first is related to the principle of mastery's evolution. The relevant section of the Phenomenology is located within spirit's step-by-step movement toward its self-realization, the relation of master and slave thus itself located within the horizon of final reconciliation. There is no place for such a notion in Sacher-Masoch's masochistic scenario, which nowhere moves beyond the possibility of overcoming the struggle between the sexes. To the contrary, the novel's sub-stories always begin at the old starting point and play out the identical effects. Their therapeutic claims are of a purely rhetorical nature. After the dismantling of each female partner, the serially masochistic narrative proceeds to the next idol, invested with the same names and attributes and obliged to fit into the familiar gameplan. Sharing this quality with other such products of the time, late nineteenth-century masochism tends to be something like a stagnant 
dialectic - an immobile perseverance in estrangement, simultaneously suffered and affirmed as a mythic fatality.

Where this first difference is basically one of Weltanschauung, the second-as odd as it may sound-is erotic in nature. The masochistic self-consciousness has no interest in the idea of unity within otherness-in concord with the self-consciousness of the opposing party. The masochist gives short shrift to a relation of interdependent acknowledgment between master and slave. Above all, he fails to recognize the domination of the dominatrix as his own attribution. He can only play his game by not facing up to its underlying rules. While wanting his mistress to accommodate herself to his projections, he does not want to take account of her having done so. She is meant to seem to act from free will, for such a belief alone can spark the shudder giving birth to the masochist's pleasure. Masochism only functions as a mystificatory enterprise.

Enlightenment about the dialectic of rule is hence the last thing the masochist can use. All of his erotic cunning is in fact aimed at undercutting this dialectic, in order to settle joyfully in a perpetually repressive space. Whoever devises a technique for transforming the experience of alienation into pleasure gains little from an identityphilosophical doctrine concerning the deeper unity of one's own and the strange. To this extent, the narrator of Venus in Furs did well to fall asleep early while reading.

Translated by Joel Golb 